\title{
Evaluation of the Prevalence of Hepatitis A in Samsun Vicinity
}

\author{
Samsun Yöresinde Hepatit A Prevalansının Değerlendirilmesi
}

\author{
Kerametțin YANIK1, Ahmet Uğur AKBAL2, Mustafa ERDIL3, Adil KARADAĞ1, Cafer EROĞLU1, \\ Murat GÜNAYDIN4
}

1 Ondokuz Mayıs University Faculty of Medicine, Department of Medical Microbiology, Samsun, Turkey

2 Directorate of Health, Samsun, Turkey

3 Maternity and Child Health Hospital, Samsun, Turkey

4/stanbul University Cerrahpaşa Faculty of Medicine, Department of Medical Microbiology, Istanbul, Turkey

\begin{abstract}
Objective: Acute viral hepatitis A (HAV) infection is a public health issue seen most commonly in childhood in autumn and early winter. In this study, our objective was to search hepatitis $A$ seroprevalence in various age groups, in terms of regional relationship between socioeconomic status and seasonal distribution in our vicinity.

Materials and Methods: 4664 serum samples that were sent to ELISA laboratories between January 2009 and December 2012 were included in the study. The serum samples were daily studied by electrochemiluminescence tests (Roche Cobas 6000 e601, Germany) for anti HAV IgM and with chemiluminescence tests (Abbott 1200, USA) for HAV IgG following the manufacturers' instructions. Anti HAV IgM positive-patients were regarded as acute, anti HAV IgG positive-patients were regarded as previously infected, and seronegative patients for both tests were regarded as negative patients. The distribution of patients by town were calculated considering the data from the AddressBased Population Registration System (Turkish Statistical Institute). Chi Square test was used for statistical analysis of the results of regional, age and seasonal distribution.

Results: Eighteen (1\%) patients were positive for HAV IgM and 1777 (38.1\%) were positive for HAV IgG. Thirteen (72\%) of HAV IgM-positive patients were childhood, 1279 (72\%) of HAV IgG-positive patients were in adulthood. The rate of HAV lgG-positive cases was determined to be significantly high $(p<0.001)$ in $0-5$ and $30-35$ age groups. Significantly higher positivity of anti HAV IgG was seen in May (10.6\%), January $(10.1 \%)$ and March $(9.9 \%)$. Comparing to the other months, significantly higher positivity of anti HAV IgM was determined to be in January (33.3), July (22.2\%) and October (22.1\%) $(p=0.004)$. The distribution of anti HAV IgG-positive cases in our
\end{abstract}

\section{ÖZET}

Amaç: Akut viral hepatit A (HAV) enfeksiyonu özellikle çocukluk yaş grubunda yaygın olarak görülen bir halk sağlığı problemi olup en sık sonbahar ve kış mevsiminin ilk aylarında görülmektedir. Çalışmamızda çeşitli yaş gruplarındaki hepatit $A$ seroprevalansının ilimizdeki bölgesel sosyo-ekonomik düzey ile ilişkisi ve mevsimsel dağılımının araştırılması amaçlanmıştır.

Gereç ve Yöntemler: 2009 Ocak-2012 Aralık arasında ELISA laboratuvarına gönderilen 4664 serum örneği çalışmaya dahil edildi. Anti HAV IgM ve IgG (Total) testleri ELISA laboratuvarına kabul edildikten sonra kemilüminesans (Abbott I2000, ABD) ve elektrokemilüminesans (Roche Cobas 6000 e601, Almanya) yöntemleriyle üretici talimatları izlenerek günlük olarak çalışımıştır. Anti HAV IgM pozitif hastalar akut, HAV IgG pozitif hastalar geçirilmiş enfeksiyon ve her iki teste göre seronegatif olanlar negatif hasta olarak değerlendirildi. Hastaların kenstsel dağılımları Adrese Dayalı Nüfus Kayıt Sistemi (TÜ|K) verileri gözetilerek hesaplanmıştır. Bölgesel, yaş ve mevsimsel dağılım sonuçlarının istatistiksel analizi için Ki kare uygunluk testi kullanılmıştır.

Bulgular: Çalışmaya alınan hastalardan 18'inde (\%1) HAV IgM, 1777'sinde $(\% 38,1)$ HAV IgG pozitif olarak saptanmıştır. HAV IgM pozitif hastaların 13'ü (\%72) çocuk yaş grubundaydı. HAV IgG pozitif hastaların 1279'u (\%72) yetişkin yaş grubundaydı. HAV IgG pozitif olguların yaş grupları arasında dağılımının 0-5 yaş grubunda en yüksek olduğu, 30-35 yaş grubunda tespit edilen artışın anlamlı pozitiflik artışı olduğu, diğer yaş gruplarında ise giderek azaldığı tespit edilmiştir. Yaş grupları arasındaki farklılı̆ın anlamlı olduğu görülmüştür. $(p=0,001)$. Anti HAV IgG'de anlamlı olarak en yüksek pozitiflik Mayıs $(\% 10,6)$, Ocak $(\% 10,1)$ ve Mart $(\% 9,9)$ aylarında görülmüştür $(p=0,001)$. Anti HAV IgM'de diğer aylara göre anlamlı yüksek pozitifliğin sırası ile Ocak $(\% 33,3)$, Temmuz $(\% 22,2)$ ve Ekim $(\% 22,1)$ aylarında olduğu tespit 


\section{ABSTRACT}

city was detected to be significantly higher in Ilkadım, Carşamba and Vezirköprü comparing to the other towns $(p<0.001)$. The distribution of anti HAV IgM positive cases was significantly higher in Canik, Carşamba and Vezirköprü ( $p=0.007)$.

Conclusion: In our vicinity with a lower socioeconomic status, higher positivity rates in winter and autumn along with some positive cases in summer and infections at early ages were observed. However, it is concluded that, especially when concerning hygiene, training the citizens and food manufacturers and sellers and strict inspections of food processing, preparation and sales places can be effective in reducing fecal and oral contamination.

Key Words: Seroprevalence, socio-economic, Anti HAV IgM, Anti HAV lgG

Conflict of interest: The authors reported no conflict of interest related to this article.

\section{Introduction}

Acute viral hepatitis $\mathrm{A}(\mathrm{HAV})$ infection is transmitted by fecal-oral route especially in childhood and is a global public health issue $(1,2)$. Anti HAV IgG positivity is high in Africa and India, has moderate prevalence in Central and Southeast Asia and in Middle East and has $93.2 \%$ prevalence in Turkey $(3,4)$. The reasons for such a widespread infection include lack of infrastructure, unsanitary municipal water and seasonal distributions (2). It is reported that HAV is most frequent in autumn and in the first months of winter. Contaminated food and water increase the infection. Hence, as well as being widespread in many geographical regions, it is more common in regions with unsanitary conditions and poorly controlled drinking water $(5,6)$.

Besides being clinically asymptomatic, HAV can show a severe acute hepatitis course (2). More severe clinical picture can be seen in adults with no previous history of infection in childhood (7). Estimating regional prevalence can contribute to diagnostic approach and problem solving in HAV infections. As of 2012, HAV vaccine is included in immunization schedule in our country.

Reliable ELISA methods are commonly used for diagnostic validations. Amongst these tests, while being sensitive, microELISA tests are relatively difficult and time-consuming. In recent years, more practical and rapid chemiluminescence methods have been preferred.

The aim of this study was to contribute to epidemiological studies by determining HAV distribution by age groups, the relationship between socioeconomic status and seasons.

\section{Materials and Methods}

Four thousand SIx hundred sixty four serum samples sent to ELISA laboratories from various clinics at Ondokuz Mayıs University Medical Faculty between January 2009 and December 2012 were included in the study. The serum samples were daily studied with electrochemiluminescence tests (Roche Cobas 6000 e601, Germany) for anti HAV IgM and with chemiluminescence

\section{ÖZET}

edilmiştir $(p=0,004)$. Anti HAV IgG pozitif olguların ilimizdeki dağılımında Ilkadım, Çarşamba ve Vezirköprü ilçelerinde diğer ilçelere göre anlamlı yüksek pozitiflik saptanmıştır $(p=0,001)$. Anti HAV IgM pozitif olgular ise Canik, Çarşamba ve Vezirköprü ilçelerinde anlamlı olarak daha yüksektir ( $p=0,007)$.

Sonuç: Sosyo - ekonomik durumu düşük olan bölgemizde, kış ve sonbahar aylarında pozitiflik oranı yüksek olmakla birlikte yaz döneminde de vakalara rastlanıldığı, enfeksiyonu geçirme yaşının ise düşük olduğu görülmüştür. Ancak özellikle hijyen konusunda, hem vatandaşların hem de yiyecek ürünleri üreten ve satanların eğitilmelerinin, yiyecek üretim, hazırlama ve satış yerlerinin daha sıkı denetlenmesinin fekal-oral bulaşı kırmada etkili olacağı sonucuna varılmıştır.

Anahtar Kelimeler: Seroprevelans, sosyo-ekonomi, Anti HAV IgM, Anti HAV IgG

Çıkar çatışması: Yazarlar bu makale ile ilgili olarak herhangi bir çıkar çatışması bildirmemişlerdir.

tests (Abbott i2000, USA) for HAV IgG following the manufacturers' instructions. Anti HAV IgM-positive patients were regarded as acute patients, anti HAV lgG-positive patients as previously infected patients and seronegative patients for both tests were regarded as negative patients. The distribution of patients by towns was calculated considering the data from the Address Based Population Registration System (Turkish Statistical Institute (TUIK) (8).

For statistical evaluation, SPSS 21.0 program (IBM Inc, Chicago, USA) was used and Chi-square test was performed. A $p$ value of less than 0.05 was considered statistically significant.

\section{Results}

Fifty-three percent of the patients were male and $47 \%$ were female. The average age of the patients was 24 years (0-93). $0.38 \%$ of the patients were positive for $\operatorname{lgM}$ and $38.1 \%$ were positive for IgG (Table 1). Thirteen (72\%) of the HAV IgM-positive subjects were in childhood, 1279 (72\%) were in adulthood.

Four hundred and ninety-eight (28\%) of the HAV IgG-positive patients were in childhood, $5(28 \%)$ were in adulthood.

High seropositivity (HAV lgG/M) was determined in Canik, and Carşamba with high socioeconomic status. Low seropositivity (HAV lgG/M) was determined in Atakum and Ilkadım with high socioeconomic status. The properties of the other cities are presented in Table 2.

Variation between the distributions of anti HAV lgG positivity by age groups was significant and even though being at its highest rate in 0-5 age group, positivity decreased with increasing age $(p<0.001)$. This decrease, compared to other age groups, showed an increase in 30-35 age group and proceeded with a re-decrease (Figure 1).

Variation of anti HAV IgM positivity between age groups was determined to be significant (Figure 2). These values started to increase after $0-5$ age group. This increase reached its highest rate in 12-17 age group and with a sharp decrease, it dropped below its initial values in 18-23 age group. 
Considering the seasons, highest positivity for anti HAV IgM was seen in January. Furthermore, positivity rate was significantly high in July and October followed by decreased rates in the other months. Anti HAV IgG positivity rate was highest in May ( $p=0.001)$. Significantly high values were observed also in January and March (Figure 3).

For the distribution of anti HAV IgM by towns, Canik (4.4\%) Asarcık (2.6\%), Vezirköprü (2.4\%) and Carşamba $(2.2 \%)$ had the highest positivity rates (Figure 4). Anti HAV IgM positivity values for towns showed statistical variations $(p=0.007)$.

For the distribution of anti HAV IgG-positive cases in our vicinity, significantly high positivity rates were determined in Ilkadım, Çarşamba and Vezirköprü $(p<0.001)$ (Figure 4).

For the distribution of anti HAV IgM positive cases in our vicinity, Canik, Asarcık, Çarşamba and Vezirköprü were determined to have significantly high prevalence $(p<0.001)$ (Figure 4).

\section{Discussion}

Due to transmission by fecal oral route, hepatitis A virus is easily transmitted to humans and is responsible for 1.4 million new cases each year. Lower socioeconomic status is especially influential in this transmission (2).

HAV infection is usually asymptomatic in children younger than 6 years of age and in older children and adults infection is usualy symptomatic with icterus and other severe symptoms and has a severe clinical course in adults. Urbanisation, improved health and sanitary conditions can reduce the incidence of infections. The paradox is that as the socioeconomic conditions improves, the frequency of the infection shifts to advanced ages with more severe course (9).

There are some studies showing the distributions of HAV by age groups and seasons in the world and in our country. In Poland, Bura et Ali determined that in Wielkopolska district anti HAV positivity rate was $3.9 \%$ in $18-30$ age group, $35.7 \%$ in $41-50$ age group, $63.9 \%$ in $61-70$ age group and $100 \%$ in those above the age of 70 years (10). In Iran, Alian et al. found that the prevalence of anti HAV infection was $8.9 \%$ in $1-5$ age group, $15.8 \%$ in $5-15$ age group, and $64.3 \%$ in $15-25$ age group (9).

In our country, Cetinkol et al. studied the distribution of hepatitis A seroprevalence by age and determined that anti HAV IgG positivity rate was $50 \%$ 0-23 months, $29.2 \%$ in 2-6 years, $17.2 \%$ in $7-10$ years, $37.5 \%$ in $11-20$ years; $96.3 \%$ in $41-50$ years and, overall seropositivity rate was found to be $57.9 \%$ (11). In their study of hepatitis A seropositivity in Van, Okur et al. found anti HAV IgM positivity rate of $8.2 \%$ in subjects $0-2$ years of age $-26 \%$ in $3-5$ years, $-16.2 \%$ in $6-10$ years, $-8.7 \%$ in $11-15$ years, $-0.6 \%$ in subjects $16-18$ years of age. They found anti HAV IgG rates of $53.1 \%$ in subjects $0-2$ years of age, $-55.7 \%$ in 3-5 years, $74.4 \%$ in $6-10$ years; $90 \%$ in $11-15$ years and $92 \%$ in those $16-18$ years of age. They determined that overall anti HAV IgG and anti HAV IgM seropositivity rates were $69.9 \%$ and $15.3 \%$, respectively (12). In their study on hepatitis A seroprevalence in various ages in Çanakkale vicinity, Arabacı et al. determined that HAV IgG positivity rate was $49.3 \%$ in ages $0-6$ years, $-54.2 \%$ in $7-11$ years, $-60.5 \%$ in $12-16$ years, $-61.4 \%$ in $17-12$ years, $-70.5 \%$ in $22-26$ years, $-86.8 \%$ in $27-31$ years, $-92.7 \%$ in $32-36$ years, $-91.5 \%$ in $37-41$ years,$98.2 \%$ in $42-46$ years, $-97.6 \%$ in $47-51$ years and $96.3 \%$ in subjects

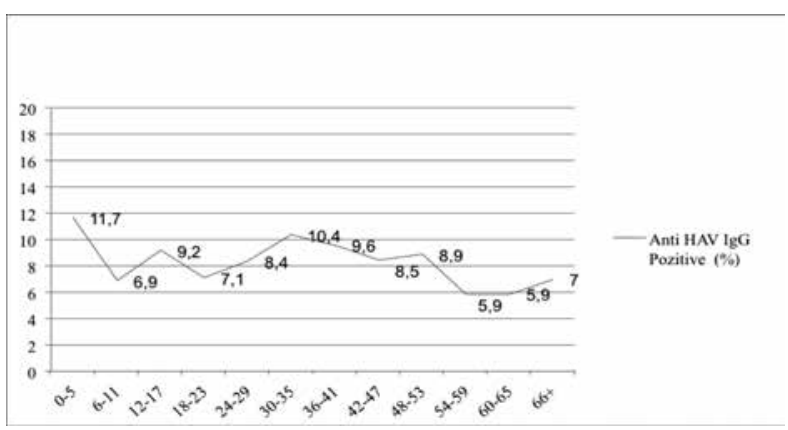

Figure 1. Anti HAV IgG positivity distribution by age groups

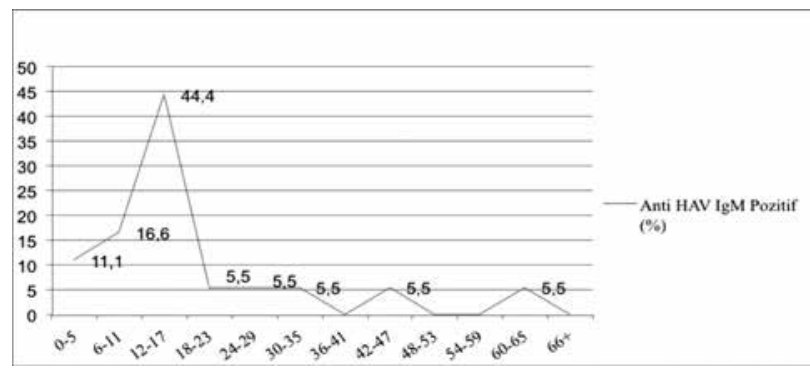

Figure 2. Anti HAV IgM positivity distribution by age groupsa

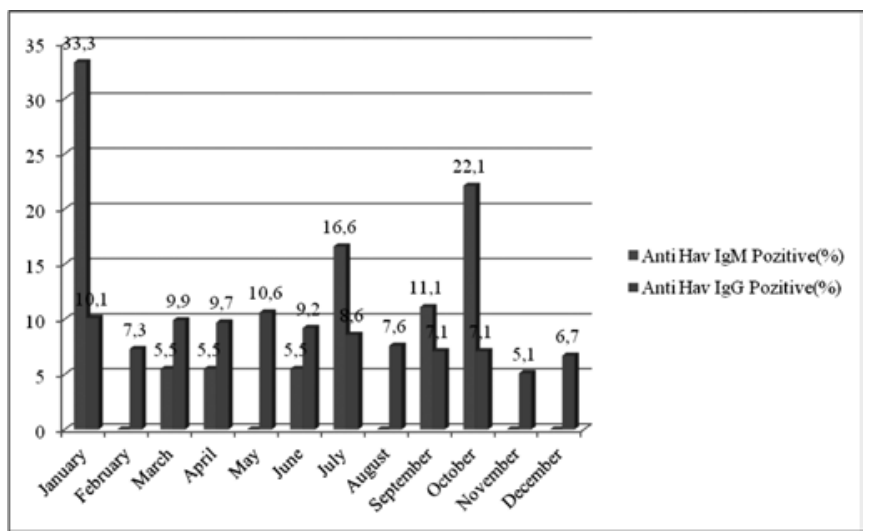

Figure 3. Anti HAV $\lg M$ and $\lg G$ positivity rate distribution by months

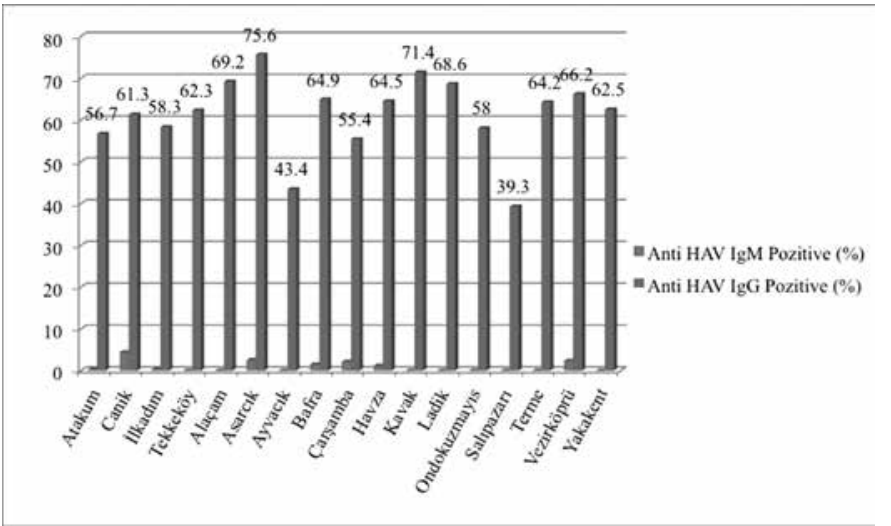

Figure 4. Anti HAV IgM and Anti HAV IgG positivity distribution by towns 
Table 1. Distribution of patients included in the study

\begin{tabular}{|l|l|l|l|l|}
\hline & Negative n (\%) & Pozitive $\mathbf{n}(\%)$ & Anti HAV Ig G (+) n (\%) & Anti HAV Ig M (+) n (\%) \\
\hline Adult n: 2296 & $1012(44.1)$ & $1284(55.9)$ & $1279(55.7)$ & $5(0.21)$ \\
\hline Child n:2368 & $1857(78.5)$ & $511(21.5)$ & $498(21)$ & $13(0.54)$ \\
\hline Total n: 4664 & $2869(61.6)$ & $1795(38.4)$ & $1777(38.1)$ & $18(0.38)$ \\
\hline
\end{tabular}

n: Patient number, (+): Positive, \%: Percent

\begin{tabular}{|c|c|c|c|c|}
\hline Towns & $\begin{array}{l}\text { Socio-economic development ranking } \\
\text { within the } 870 \text { towns }\end{array}$ & Development Group & Anti HAV IgM $(+)(n / N) \%$ & Anti HAV IgG $(+)(n / N) \%$ \\
\hline Canik & 25 & 2 & $(4 / 90) 4.4$ & $(119 / 194) 61.3$ \\
\hline İlkadim & 25 & 2 & $(1 / 287) 0.3$ & $(427 / 733) 58.3$ \\
\hline Tekkeköy & 226 & 3 & $(-/ 68)-$ & $(71 / 114) 62.3$ \\
\hline Çarşamba & 282 & 3 & $(4 / 184) 2.2$ & (148/267) 55.4 \\
\hline Terme & 436 & 3 & $(-/ 121)-$ & $(111 / 173) 64.2$ \\
\hline Ladik & 459 & 3 & $(-/ 25)-$ & $(24 / 35) 68.6$ \\
\hline Alaçam & 645 & 4 & $(-/ 64)-$ & $(54 / 78) 69.2$ \\
\hline Vezirköprü & 710 & 5 & $(3 / 125) 2.4$ & $(102 / 154) 66.2$ \\
\hline Salıpazarı & 761 & 6 & $(-/ 19)-$ & $(11 / 28) 39.3$ \\
\hline Ayvacık & 789 & 6 & $(-/ 35)-$ & $(23 / 53) 43.4$ \\
\hline Asarcık & 796 & 6 & $(1 / 39) 2.6$ & $(34 / 45) 75.6$ \\
\hline
\end{tabular}

$\mathrm{N}$ : Total patient, n: Positive patient (+): Positive, \%: Percent

over 52 years of age. They found that the prevalence of exposure to HAV was $78.87 \%$ and overall acute HAV seroprevalence was $12 \%$ in all age groups (13).

We observed that anti HAV IgM positivity rate was higher in childhood, compared to that in adulthood, however, anti HAV IgG positivity rate was higher in adulthood. This is in compliance with the previous studies. Furthermore, when the distribution by age groups is examined, it can be understood that rather than adult patients, patients in childhood are at higher risk for disease. This fact highlights the importance of vaccination.

In studies on distribution of HAV prevalence in population by seasons, it was emphasized that anti HAV IgM positivity had higher rates particularly in winter and autumn (14). In our study demonstrating higher positivity in winter and autumn, we identified acute cases in summer as well.

High HAV seropositivity was identified in regions with lower socioeconomic status. It is emphasized that this may be due to unsanitary conditions and uncontrolled water resources (15). In our study, when we evaluate positivity with regard to socioeconomic status and water distributions, high positivity rates were identified in towns with lower socioeconomic status, such as Asarcık, Kavak and Alaçam (Table 2) (16). These regions have various water resources as well. However, higher seropositivity in rural regions can be associated with larger population. Noteworthily, rural population in Samsun (32.9) is approximately 10\% higher than the average rural population in Turkey (22.7\%) (17). In terms of seropositivity, no significant variations between central towns with similar water resources and socioeconomic status were identified. High seropositivity in central towns such as Canik and Ilkadım that have water supplies from advanced water treatment plants can be explained by domestic migration from towns with lower socioeconomic status. As a matter of fact, Verhoef et al. found that the overall seroprevalence increased in Holland from 35\% in 19951996 to $39 \%$ in 2006-2007 due to increased immigrant population (17). In this study, it is remarkable that the seropositivity rate among subjects included in the study was higher (38.1\%) compared to that in the literature $(2,9,10,11,12,13,14,15,18)$.

As a result, it was observed that the prevalence of antibodies to HAV was high in vicinities with lower socioeconomic status, and in terms of seasons, along with some positive cases in summer, positivity rates were higher in winter and autumn, and the prevalence of infections occurring at early ages was low, in compliance with the literature. However, it is concluded that, especially when concerning hygiene, training both citizens and food manufacturers and sellers as well as strict inspections of food processing, preparation and sales places can be effective in reducing HAV prevalence. 


\section{References}

1. Leung AK, Kellner JD, Davies HD. Hepatitis A: a preventable threat. Adv Ther .2005; 22: 578-586.

2. Jacobsena $\mathrm{KH}$, Wiersmab ST. Hepatitis A virus seroprevalence by age and world region, 1990 and 2005. 2010; 28: 6653-6657.

3. Bell BP. Global epidemiology of hepatitis A: implications for control strategies. 10th International Symposium on Viral Hepatitis and Liver Disease. 2002; 14.

4. Tozun N, Ozdogan OC, Cakaloglu Y, Idilman R, Karasu Z, Akarca US, Kaymakoglu S, Ergonul Ö. A. Nationwide Prevalence Study And Risk Factors For Hepatitis A, B, C And D Infections In Turkey. Hepatology.2010; 52:697.

5. Taşkesen M, Taş MA, Ecer S, Özel AK, Karabiberoğlu S. 155 Akut Viral Hepatit A Olguların Klinik ve Laboratuar Bulgularının Değerlendirilmesi. Dicle Tıp Dergisi, 2008;35(3):155-158.

6. Michielsen PP, Van Damme P. Viral hepatitis and pregnancy. Acta Gastroenterol Belg .1999; 62: 21-9.

7. Curry MP, Chopra S. Principles and Practice of Infectious Diseases. Mandell GL, Bennett JE, Dolin R. Acute Viral Hepatitis. Sixth edition, Philadelphia: Elsevier Churchill Livingstone .2009; 1426-1440.

8. Seçilmiş Göstergelerle Samsun 2012, Türkiye Istatistik Kurumu, 2012.

9. Alian S, Ajami A, Ghasemian R, Yadegarinia D, Age-specific seroprevalence of hepatitis A in Sari. EMHJ. 2011;17(10):754758.

10. Bura M, Bura A, Adamek A, Michalak M, Marszaiek $A$, Hryckiewicz K, Mozer-Lisewska I. Seroprevalence of hepatitis A virus antibodies (anti-HAV) in adult inhabitants of Wielkopolska region, Poland the role of simple demographic factors. Annuals of Agricultural and Environmental Medicine. 2012; 19(4):738741.

11. Çetinkol Y, Yıldırım A, Ünye Devlet Hastanesine Başvuran Hastalarda Hepatit A Seroprevalansı. Kocatepe Tıp Dergisi.2011;12: 18-22 .

12. Okur M, Erbey $F$, Acar MN, Güven A, Kaya A. Van Illi Ve Çevresinde 0-18 Yaşları Arasındaki Çocuklarda Hepatit A Seropozitifliği.Düzce Tıp Dergisi.2011; 13(2): 6-9.

13. Arabacı F, Oldacay M. Çanakkale Yöresinde Çeşitli Yaş Gruplarında Hepatit A Seroprevalansı ve Akut Hepatitli Olgularda Hepatit A Sıklığı. Çocuk Enf. Derg. 2009;3:58-61.

14. Öztürk Z, Erol S, Ertek M, Taşyaran MA. Akut Viral Hepatit Olgularının Değerlendirilmesi.V. Ulusal Viral Hepatit Sempozyumu. 2000

15. Jacobsen KH, Koopman JS. The effects of socioeconomic development on worldwide hepatitis A virus seroprevalence patterns. International Journal of Epidemiology 2005;34:600609.

16. IIçelerin Sosyo-Ekonomik Gelişmişlik Sıralaması Araştırması. Başbakanlık Devlet Planlama Teşkilatı, 2004.

17. Verhoef $L$, Boot HJ, Koopmans M, Van Der Klis F, Reimerink J, Van Pelt W. Changing risk proŞle of hepatitis A in The Netherlands: A comparison of seroprevalence in 1995-1996 and 2006-2007. Epidemiol. Infect. 2011;139:1172-1180.

18. Koroglu M, Demiray T, Terzi HA, Altindis M. Seroprevalence of Hepatitis A among Different Age Groups in Sakarya and Review of The Literature, Viral Hepatitis Journal 2014;20:110-114. 